\title{
Strategi Peningkatan Pendapatan Rumah Sakit Berdasarkan Analisis SWOT
}

\author{
Nina Fentiana ${ }^{1}$, Daniel Ginting ${ }^{2 *}$ \\ ${ }^{1,2}$ Universitas Sari Mutiara Indonesia, Jalan Kapten Muslim No 79 Medan, 20120 \\ *Correspondence email: dginting60@gmail.com
}

\begin{abstract}
Abstrak. Rumah sakit sebagai badan usaha dibidang jasa mempunyai misi tersendiri yaitu menyajikan pelayanan berkualitas dengan tercapainya kepuasan pasien yang ditandai dengan berkurangnya keluhan (complain) dari pelanggan, peningkatan kunjungan sehingga menunjukkan kinerja perusahaan yang tinggi. Analisis SWOT merupakan identifikasi berbagai faktor secara sistematis untuk merumuskan strategi perusahaan. Penelitian ini untuk menemukan strategis yang tepat dari adanya opportunity atau peluang, dimana terdapat pangsa pasar yang luas yang memungkinkan rumah sakit dapat tumbuh dan berkembang. Fokus penelitan ini adalah rencana strategis dalam upaya peningkatan pendapatan rumah sakit dengan menganalisis gambaran kinerja rumah sakit dalam 3 tahun terakhir dari tahun 2017 sampai tahun 2019. Penelitian dilakukan dengan pendekatan kualitatif di salah satu rumah sakit di Kota Langsa. Berdasarkan hasil diagram SWOT maka rencana strategis yang akan dilaksanakan untuk peningkatan pendapatan rumah sakit adalah dengan melaksanakan standarisasi SDM (jumlah uraian tugas pendidikan SOP), efisiensi biaya, pelayanan unggulan, survei kepuasan pasien dan melaksanakan efisiensi pembiayaan umum langsung dan investasi.
\end{abstract}

Kata kunci: finansial; kinerja; rumah sakit; SWOT

Abstract. The hospital as a business entity in the service sector has its own mission, which is to provide quality services with the achievement of patient satisfaction which is marked by reduced complaints from customers, increased visits so that it shows high company performance. SWOT analysis is a systematic identification of various factors to formulate a company strategy. This research is to find the right strategic opportunity or opportunity, where there is a large market share that allows hospitals to grow and develop. The focus of this research is a strategic plan in an effort to increase hospital income by analyzing a picture of hospital performance in the last 3 years from 2017 to 2019. The study was conducted using a qualitative approach in one of the hospitals in Langsa City. Based on the results of the SWOT diagram, the strategic plan that will be implemented to increase hospital income is to implement standardization of human resources (number of SOP educational task descriptions), cost efficiency, superior services, patient satisfaction surveys and implement efficiency of direct general financing and investment.

Keywords: financial; performance; hospital; SWOT

\section{PENDAHULUAN}

Rumah sakit sebagai salah satu institusi penyelenggara layanan kesehatan dituntut untuk memliki keunggulan daya saing, mampu menyajikan pelayanan berkualitas dengan harga wajar serta bersaing. Tujuan utama rumah sakit dalam menyajikan pelayanan berkualitas adalah tercapainya kepuasan pasien yang ditandai dengan berkurangnya keluhan (complain) dari pelanggan, peningkatan kunjungan sehingga menunjukkan kinerja perusahaan yang tinggi. Rumah sakit sebagai badan usaha dibidang jasa mempunyai misi tersendiri sama seperti badan usaha lainnya. Produk utama rumah sakit adalah pelayanan pada pasien dan sasaran utamanya adalah perawatan dan pengobatan serta kesehatan pada penderita sakit (Bustami, 2011).

Pengelolaan rumah sakit sebagai perusahaan jasa, dimana dalam menjalankan kegiatannya diperlukan tenaga kerja cukup banyak yang menguasai teknologi, alat-alat medis, pelayanan fasilitas dan sarana yang memadai, penyediaan makanan, peralatan serta sistem manajemen administrasi yang terkoordinasi dengan baik, untuk menghindari hal-hal yang tidak di inginkan, maka pihak manajemen dituntut untuk memiliki kemampuan dalam mengelola dan menghasilkan sumber-sumber ekonomis pada rumah sakit secara sistematis, efisien, dan efektif, termasuk perencanaan strategis yang mantap (Adisasmito, 2007).

Analisis SWOT merupakan identifikasi berbagai faktor secara sistematis untuk merumuskan strategi perusahaan. Secara umum, penentuan strategi yang tepat bagi perusahaan dimulai dengan mengenali opportunity (peluang) dan treats (ancaman) yang terkandung dalam lingkungan eksternal serta memahami strength (kekuatan) dan weakness (kelemahan) pada aspek internal perusahaan. Dengan demikian, perusahaan mampu bersaing dan mencapai tujuan secara efektif dan efisien (Rangkuti, 2013).

Strategi perusahaan dapat dilakukan dengan berbagai cara. Cara-cara suatu perusahaan dalam menggunakan keseluruhan atau beberapa strategi yang akan dilakukan disebut dengan formulasi strategi. Formulasi strategi terdiri dari tiga macam yaitu : formulasi strategi koorporat dimana perusahaan menganalisa lingkungan perusahaan untuk menentukan arah perusahaan di masa depan, formulasi strategi unit bisnis guna mengetahui kekuatan perusahaan terhadap 
persaingan industri serta formulasi strategi fungsional yang dilakukan untuk setiap fungsi-fungsi dari suatu perusahaan, salah satunya adalah strategi pemasaran (Assauri, 2013).

Kaitannya dengan penelitian ini untuk menemukan strategis yang tepat dari adanya opportunity atau peluang, dimana terdapat pangsa pasar yang luas yang memungkinkan rumah sakit dapat tumbuh dan berkembang. Kebijakan investasi rumah sakit harus mempertimbangan tingkat profitabilitas dari setiap kebijakan investasi, dan melalui sebuah perencanaan strategis yang baik dalam memilih jenis pelayanan yang harus dikembangkan (Indra, 2006). Fokus penelitan ini adalah rencana strategis dalam upaya peningkatan pendapatan rumah sakit dengan menganalisis gambaran kinerja rumah sakit dalam 3 tahun terakhir dari tahun 2017 sampai tahun 2019. Data kinerja rumah sakit dalam penelitian ini disajikan sebagai berikut:

Tabel 1. Kunjungan Rumah Sakit Tahun 2016-2019

\begin{tabular}{lcccc}
\hline & $\mathbf{2 0 1 6}$ & $\mathbf{2 0 1 7}$ & $\mathbf{2 0 1 8}$ & $\mathbf{2 0 1 9}$ \\
\hline Rawat Jalan & 44.439 & 16.468 & 22.521 & 6.150 \\
Rawat Inap & 6.537 & 7.812 & 7.744 & 5.122 \\
Jumlah & $\mathbf{5 0 . 9 7 6}$ & $\mathbf{2 4 . 2 8 0}$ & $\mathbf{3 0 . 2 6 5}$ & $\mathbf{1 1 . 2 7 2}$ \\
\hline
\end{tabular}

Sumber: Manajemen Rumah Sakit

Kunjungan rawat jalan dan rawat inap rumah sakit dalam 4 tahun terahir menurun drastis:

- Tahun 2016 sebesar 50.976 kunjungan

- Tahun 2017 menjadi 24.280 kunjungan

- Tahun 2018 menjadi 30285 kunjungan

- Tahun 2019 menjadi 11. 272 kunjungan

Penurunan mencapai $77,88 \%$ dalam 4 tahun terahir. Kinerja rawat inap di tahun 2019 seperti ditunjukkan tabel berikut.

Tabel 2. Kinerja Rawat Inap 2018

\begin{tabular}{llc}
\hline No & \multicolumn{1}{c}{ Variabel } & Nilai \\
\hline 1 & BOR & 58,50 \\
2 & LOS & 3,30 \\
3 & BTO & 4,30 \\
4 & TOI & 2,6 \\
\hline
\end{tabular}

Tabel diatas menunjukkan bahwa BOR pada tahun 2018 masih belum menunjukkan nilai efisien ( $\geq 75 \%)$. Berdasarkan data diatas maka dirancang penelitian untuk mengetahui rencana strategis rumah sakit dalam upaya peningkatan pendapatan rumah sakit.

\section{METODE}

Penelitian dilakukan dengan pendekatan kualitatif di salah satu rumah sakit di Kota Langsa karena pada penelitian kualitatif ini peneliti mengenal baik objek yang diteliti, peneliti mengenal dengan baik para nara sumber yang dilakukan diskusi atau wawancara, penelitian dilakukan dengan cara pengumpulan data participant observation dan dilakukan wawancara yang lebih mendalam (Sugiyono, 2010).

Penelitian kualitatif ini memandang realita sosial sebagai sesuatu yang utuh, kompleks dan dinamis serta mempunyai hubungan gejala bersifat interaktif (resiprokal). Proses perancangan strategis memandang identitas bisnis sebagai suatu proses bisnis yang berada dalam lingkungan industri yang kompetitif dengan segala macam persoalan yang memerlukan proses pengelolaan manajemen secara kompherensif. Rumah sakit sebagai entitas ekonomi yang ingin tumbuh dan berkembang perlu melakukan proses perancangan manajemen melalui sebuah kajian ilmiah yang terpola, sehingga proses pengelolaan manajemen dapat dilakukan secara terarah melalui tahap-tahap perancangan strategis.

\section{HASIL DAN PEMBAHASAN}

Dengan metode penelitian berdasarkan wawancana yang mendalam dengan bagian terkait dan observasi langsung ditemukan faktor kekuatan yang diperoleh dapat dirumuskan sebagai berikut:

1. SDM mencukupi dari segi jumlah.

2. Manajemen klinik dibawah naungan satu administrasi telah bekerjasama dengan BPJS.

3. Sarana dan prasarana cukup memadai

4. Memiliki administrasi penunjang dan laporan keuangan secara rutin ke perusahaan.

5. Sentralisasi sarana dan prasarana.

6. Pendapatan meningkat.

7. Rawat inap meningkat.

Selain kekuatan yang didapat dalam hasil wawancara dengan bagian terkait diperoleh juga faktorfaktor kelemahan sebagai berikut:

1. SDM perlu distandarkan (jumlah, uraian tugas, background pendidikan, SOP)

2. Pengeluaran cenderung meningkat

3. Rawat jalan menurun

4. Jumlah tempat tidur tidak sesuai dengan kebutuhan

5. Tingginya biaya langsung dan investasi

6. Dokter spesialis tidak menetap

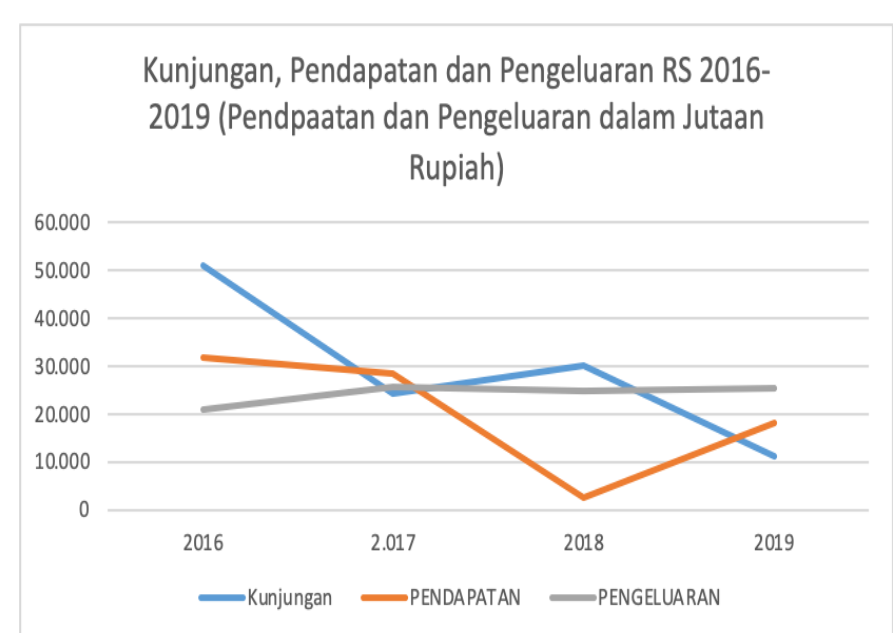

Gambar 1. Kinerja Rumah Sakit Tahun 2016-2019 
Berdasarkan audit terhadap faktor eksternal yang mempengarui proses lingkungan usaha rumah sakit, maka dalam rangka perumusan tujuan dan pemilihan strategis yang tepat untuk meningkatkan kinerja rumah sakit sesuai dengan harapan yang ditargetkan oleh rencana strategis rumah sakit akan terjadi peningkatan kunjungan maka akan dilakukan proses perumusan strategis melalui analisa SWOT (Ismail, 2012).

Analisa SWOT digunakan untuk menjaring presepsi dan penilaian yang diperoleh melalui informasi - informasi internal yang diperoleh melalui literatur dan studi pustaka serta hasil dari wawancara dari bagian bagian terkait serta hasil dari observasi yang mandalam oleh penulis.Setelah di peroleh beberapa alternatif maka dilakukan pemilihan prioritas berdasarkan kriteria yang ditetapkan. Penentuan prioritas ini dipandang perlu dilakukan dengan alasan bahwa untuk mengimplementasikan seluruh strategis yang telah diperoleh melalui analisa SWOT (Suparto, 2012). Tahap-tahap dibawah ini akan dilakukan proses pemilihan srategis baik melalui faktor - faktor faktor internal.

\section{Analisa Audit Internal}

Analisis data terhadap faktor internal rumah sakit diperoleh melalui data-data literatur pustaka rumah sakit dan hasil wawancara yang mendalam serta observasi secara langsung maka diperoleh kekuatan dan kelemahan bagi rumah sakit melalui Consencus Decission Making Group (CDMG) ditentukan bobot dan rating untuk masing-masing faktor kunci untuk mendapatkan nilai skore IFE (Rangkuti, 2013). Hasil evaluasi dengan menggunakan matirks IFE sebagai berikut:

\section{Faktor - faktor Peluang}

1. Menciptakan Pelayanan Unggulan

2. Survei kepuasan BPJS serta pendekatan yang saling menguntungkan

3. SDM:
a. meningkatkan kualitas pekerja
b. menyesuaikan jumlah SDM dengan beban kerja
c. beban kerja terukur

4. Pendapatan : meningkatkan kunjungan Non BPJS (perlu market baru)

5. Efisiensi biaya umum

6. Efisiensi biaya langsung

7. Efisiensi biaya investasi

\section{Faktor- faktor Ancaman}

1. Persaingan antara Rumah Sakit semakin meningkat.

2. Pengeluaran terlalu besar sehingga perlu disubsidi PT Cut Meutia Medika Nusantara Kebijakan PTP yang tidak mencampuri biaya operasional.

\section{Internal Factor Evaluation (IFE) Matrix}

Faktor kunci yang telah ditentukan dalam proses indetifikasi audit intenal digunakan untuk tahap pemilihan strategis, tahap selanjutnya sebelum melakukan pemilihan strategis ditentukan faktor -faktor kunci dengan menggnakan IFE mariks. Seluruh kompenen dalam SDMG akan ditentukan rating dari masing-masing komponen sehingga mendapatkan nilai skor IFE (Rangkuti, 2013). Penentuan IFE matriks mencakup penilaian terhadap kekuatan dan kelemahan yang diperoleh melalui hasil wawancara yang mendalam dan obserfasi secara langsung di rumah sakit. Hasil penentuan IFE matriks akan dilihat pada tabel dibawah ini.

Tabel 3. IFE Matriks

\begin{tabular}{|c|c|c|c|c|}
\hline No. & Analisa SWOT & Bobot & Rating & Bobot X Rating \\
\hline \multicolumn{5}{|c|}{ Strenght } \\
\hline 1 & SDM mencukupi dari segi jumlah & 4 & 0,1 & 0,4 \\
\hline 2 & Dokter spesialis lengkap & 5 & 0,2 & 1 \\
\hline 2 & Manajemen klinik dibawah naungan satu administrasi yaitu PT & 3 & 0,1 & 0,3 \\
\hline 3 & Kerjasama dengan BPJS & 5 & 0,1 & 0,5 \\
\hline 4 & Sarana dan prasarana cukup memadai & 3 & 0,1 & 0,3 \\
\hline 5 & $\begin{array}{l}\text { Memiliki administrasi penunjang dan laporan keuangan secara rutin ke } \\
\text { perusahaan }\end{array}$ & 3 & 0,1 & 0,3 \\
\hline 6 & Sentralisasi sarana dan prasarana & 3 & 0,1 & 0,3 \\
\hline 7 & Pendapatan meningkat & 4 & 0,1 & 0,4 \\
\hline \multirow[t]{2}{*}{8} & Rawat inap meningkat & 4 & 0,1 & 0,4 \\
\hline & JUMLAH & & 1,0 & 3,9 \\
\hline \multicolumn{5}{|c|}{ Weakness: } \\
\hline 1 & $\begin{array}{l}\text { SDM perlu distandarkan (jumlah, uraian tugas, background pendidikan, } \\
\text { SOP) }\end{array}$ & 5 & 0,3 & 1,5 \\
\hline 2 & Pengeluaran cenderung meningkat & 4 & 0,2 & 0,8 \\
\hline 3 & $\begin{array}{l}\text { Kunjungan Rawat jalan } \\
\text { menurun }\end{array}$ & 4 & 0,2 & 0,8 \\
\hline 5 & Tingginya biaya langsung dan investasi & 4 & 0,3 & 1,2 \\
\hline & JUMLAH & & 1,0 & 4,3 \\
\hline \multicolumn{5}{|c|}{ Threatened } \\
\hline 1 & Persaingan antara rumah sakit semakin banyak. & 3 & 0,3 & 0,9 \\
\hline
\end{tabular}


2 Pengeluaran terlalu besar sehingga perlu disubsidi PT

3 Belum diketahui secara pasti penyebab turunnya kunjungan

$4 \quad$ Tingginya biaya langsung dan investasi JUMLAH

\section{Opportunity}

$1 \quad$ Menciptakan Pelayanan Unggulan

2 Survei kepuasan BPJS serta pendekatan yang saling menguntungkan

3 SDM :

- meningkatkan kualitas pekerja

- menyesuaikan jumlah SDM dengan beban kerja

- beban kerja terukur

4 Pendapatan : meningkatkan kunjungan Non BPJS (perlu market baru)

5 Efisiensi biaya umum,langsung, investasi Jumlah $\begin{array}{lll}4 & 0,2 & 0,8\end{array}$

$4 \quad 0,3 \quad 1,2$

$\begin{array}{lll}3 & 0,2 & 0,6\end{array}$

2,5

$\begin{array}{lll}4 & 0,2 & 0,8\end{array}$

$\begin{array}{lll}3 & 0,2 & 0,6\end{array}$

$3 \quad 0,2 \quad 0,6$

$3 \quad 0,2 \quad 0,6$
Keterangan :

Sangat kuat $=5$

Faktor Kuat $=4$

Faktor Cukup $=3$

Lemah $=2$

Sangat lemah $=1$

\section{Matrik SWOT}

\begin{tabular}{|l|l|l|}
\hline & Oppurtunity & Threat \\
Strenght & Kuadran I (SO) & Kuadran III (ST) \\
Weakness & Kuadran II (WO) & Kuadran IV (WT) \\
\hline
\end{tabular}

Tabel skoring dan pembobotan Rumah Sakit menunjukkan skor:

1. kekuatan nilai 3,9

2. kelemahan nilai 4,3

3. ancaman nilai 2,5

4. peluang nilai 3,2 berikut:

Hasil diagram Rumah Sakit adalah sebagai

1. Kuadran 1: $\mathrm{SO}=3,9 \times 3,2=12,48$

2. Kuadran $2: \mathrm{WO}=4,3 \times 3,2=13,76$

3. Kuadran $3: \mathrm{ST}=3,9 \times 2,5=9,75$

4. Kuadran 4: $\mathrm{WT}=4,3 \times 2,5=10,75$

Menunjukkan bahwa Rumah Sakit mempunya kelemahan yang besar namun mempunyai peluang yang besar. Pengertian kuadran diagram adalah sebagai berikut:

\section{Kuadran I}

Dalam kuadran ini rumah sakit layak dikembangkan karena besarnya faktor kekuatan dan peluang

\section{Kuadran II}

Dalam kuadran ini rumah sakit harus mempertimbangkan dan mengupayakan upaya mengurangi kelemahan dan mendapatkan peluang.

\section{Kuadran III}

Dalam kuadran ini rumah sakit perlu memperkuat kekuatan dan mengurangi ancaman.

\section{Kuadran IV}

Dalam kuadran ini rumah sakit layak mempertimbangkan pengembangannya karena besarnya unsur kelemahan dan ancaman.

Kuadran I merupakan situasi yang menguntungkan karena rumah sakit memiliki peluang dan kekuatan yang baik dan bisa dioptimalkan dengan cara meminimalisir segala kelemahan dan ancaman. Strategi yang digunakan adalah mendukung strategi agresif yang bertujuan untuk memajukan program serta meminimalisir kelemahan yang berasal dari sumber daya manusia (pekerja) (A.B, 2014). Cara yang digunakan antara lain: meningkatkan mutu pelayanan dengan strategi memperbaiki dan mengembangkan sarana dan prasarana yang ada; mengadakan pelatihan yang dikhususkan untuk para dokter, perawat, bidan dan tenaga kerja yang lainnya untuk memperbaiki kualitas SDM; meningkatkan keamanan; serta menetapkan kebijakan baru yang mendukung perkembangan rumah sakit (Prawirosentono Suyadi, 2014).

Hal lain yang dapat dilakukan untuk peningkatan pendapatan rumah sakit adalah strategi agresif, yaitu mengembangkan kekuatan yang ada dan meningkatkan serta mempertahankan peluang yang ada. Strategi ini dapat dilakukan melalui pendekatan-pendekatan kepada masyarakat sekitarnya sebagai potential customer, dengan cara penyebaran pamflet, melakukan penyuluhan maupun seminar kesehatan, pemeriksaan maupun pengobatan gratis. Selain itu, strategi penetrasi pasar juga dapat dilakukan dengan memasang iklan pada media cetak, elektronik maupun internet dan publisitas. Sementara itu, pengembangan produk dapat dilakukan dengan menambah fasilitas kesehatan dengan teknologi terbaru maupun menambah sarana pelayanan medik (Prabhakar V Gantasala, 2011).

Sehubungan dengan hasil diagram SWOT maka rencana strategis yang akan dilaksanakan seperti uraian berikut:

1. Standarisasi SDM (jumlah uraian tugas pendidikan SOP)

2. Efisiensi biaya

3. Pelayanan unggulan

4. Survei kepuasan pasien 
5. Melaksanakan efisiensi pembiayaan umum langsung dan investasi
Hasil rancangan strategi berdasarkan analisa SWOT dan dampak perspektif finansial seperti ditunjukkan pada tabel berikut.

Tabel 4. Rancangan Perspektif Finansial

\begin{tabular}{|c|c|c|}
\hline No & Upaya & Perspektif Finansial \\
\hline 1 & Mewujudkan SDM yang berkompeten & Efisiensi kendali biaya \\
\hline 2 & Melaksanakan Survay mengetahui penurunan kunjungan & Kunjungan meningkat pendapatan meningkat \\
\hline 3 & $\begin{array}{l}\text { Mewujudkan pelayanan unggulan mencegah peserta BPJS } \\
\text { pindah Faskes }\end{array}$ & $\begin{array}{l}\text { Meningkatkan pendapatan dengan mencegah peserta } \\
\text { BPJS pindah Faskes }\end{array}$ \\
\hline 4 & $\begin{array}{l}\text { Peningkatan Status Klinik Cot Girek menjadi Rumah Sakit } \\
\text { Kelas D }\end{array}$ & Peningkatan pendapatan, penambahan tempat tidur \\
\hline 5 & Pengadaan dokter spesialis sendiri & $\begin{array}{l}\text { Jangka pendek mengurangi pendapatan, jangka Panjang } \\
\text { meningkatkan pendapatan }\end{array}$ \\
\hline 6 & Mewujudkan efisiensi biaya umum dan langsung & Mengurangi pengeluaran \\
\hline
\end{tabular}

\section{SIMPULAN}

Berdasarkan analisis SWOT dapat disimpulkan bahwa perbaikan finansial rumah sakit dalam jangka pendek maupun jangka panjang dengan memperbaiki faktor-faktor:

1. Mewujudkan SDM yang berkompeten

2. Melasanakan survei

3. Mewujudkan pelayanan unggulan

4. Pengadaan dokter spesialis sendiri

5. Mewujudkan efisiensi biaya umum dan langsung

\section{DAFTAR PUSTAKA}

Adisasmito, W. (2007). Sistem Manajemen Lingkungan Rumah Sakit. Jakarta: PT.Raja Grafindo Persada Jakarta.

A.B, S. (2014). Manajemen Strategi Komprehensif. Jakarta: Erlangga.

Assauri, S. (2013). Manajemen Pemasaran; Dasar, Konsep dan Strategi. Jakarta: PT.Grafindo Persada.

Bustami, M. (2011). Penjamin Mutu Pelayanan Kesehatan dan Akseptibiliasnya. Jakarta: Erlangga.

Indra, B. (2006). Akuntansi kesehatan. Jakarta: Erlangga.

Ismail, S. (2012). Manajemen strategic. Jakarta: Erlangga.

Prabhakar V Gantasala, P. R. (2011). Sanaya Human Capital-Startaegic Palnning and Human Capital Case Study. International Journal Of Business and Social Science Vol.25 (Spesial Issue).

Prawirosentono Suyadi, D. P. (2014). Manajemen Strategik dan Pengambilan keputusan Korporasi. Jakarta: Bumi Aksara.

Rangkuti. (2013). Analisis SWOT teknik membedah kasus bisnis, cara perhitungan bobot, rating, dan OCAI. Jakarta: PT.Gramedia Pustaka Utama.

Sartono, A. (2008). Manajemen Keuangan Teori dan Aplikasi. Yogyakarta: BPFE Yogyakarta.

Sugiyono. (2010). Metode Penelitian Kuantitaif, kualitatif dan $R \& D$. Bandung: Alfabeta.
Suparto, A. (2012). Manajemen rumah sakit. Jakarta: PT Pustaka Sinar Harapan. 